\title{
CAPITAL ACCUMULATION, INCOME DISTRIBUTION, TECHNICAL PROGRESS AND ENDOGENOUS MONEY IN A POST-KEYNESIAN MACRODYNAMIC MODEL
}

\author{
Luciano Dias Carvalho ${ }^{1}$ \\ José Luís Oreiro ${ }^{2}$
}

Área 5 - Crescimento, Desenvolvimento Econômico e Instituições.

Código JEO: E12; E51; E22; O31; O42.

Resumo: O objetivo do presente artigo é analisar, por meio de simulação computacional, as trajetórias dinâmicas da taxa de acumulação de capital, da taxa de lucro, da taxa de juros e do grau de utilização da capacidade diante de mudanças exógenas do ritmo do progresso tecnológico e da propensão a poupar dos capitalistas. A simulação foi realizada a partir de um modelo macrodinâmico pós-keynesiano que leva em consideração a interação entre o lado real e monetário da economia. Dentre outros resultados, as simulações mostraram que: (i) a taxa de lucro é significativamente elástica com relação a um choque tecnológico positivo, ao passo que a taxa de juros e o grau de utilização da capacidade são pouco sensíveis a esse tipo de choque; e (ii) a confirmação do paradoxo na frugalidade, segundo o qual o aumento da propensão a poupar dos capitalistas acaba por reduzir o nível da poupança agregada, a taxa de lucro e o grau de utilização da capacidade.

Palavras-Chave: Modelos Macrodinâmicos, Teoria Pós-keynesiana, Simulação Computacional.

\begin{abstract}
The objective this paper is to analyze the dynamic path of the profit rate, the interest rate, the rate of capital accumulation and the degree of utilization of the productive capacity - face exogenous changes of the intensity of technological progress and the propensity to save of capitalists within a Post-Keynesian macroeconomic dynamic model that join the real and monetary side of the economy. The computational simulation allowed investigating the degree of proximity of the model to the dynamics of a real economy. The simulation showed, amongst other results, that: (i) the profit rate is significantly elastic with regard to the rate of technological progress, while the interests rate and the degree of utilization of the capacity are little sensible to this variable; and (ii) the confirmation of the paradox of the thrift, according to which an increase of the propensity to save of the capitalists reduces the level of the aggregate saving.
\end{abstract}

Keywords: Macroeconomic Dynamic Models; Post-Keynesian Theory; Computational Simulation.

Junho 2007

\footnotetext{
${ }^{1} \mathrm{PhD}$ candidate in economics at Federal University of Paraná (UFPR). E-mail: lucianodc@gmail.com.

${ }^{2}$ Associate Professor of Economics at Federal University of Paraná (UFPR), Curitiba, Brazil [e-mail: joreiro@ufpr.br, webpage: www.joseluisoreiro.ecn.br]. Address: Av. Pref. Lothario Meissner 632, Térreo, Jardim Botânico, Curitiba, Brazil. Zip Code: 80210-170.
} 


\section{INTRODUCTION}

The objective of this paper is to analyze the dynamic path of some macroeconomic variables - in particular, the profit rate, the interest rate and the degree capacity utilization - in a Post Keynesian macrodynamic model of capital accumulation, income distribution and technological progress. In order to do that, we will present the basic structure of a Post Keynesian macroeconomic dynamic model of the third generation $^{l}$ whose main features - that distinguish it from other Post Keynesian models - are of great importance given the technological progress for the determination of long-term dynamics of the economy and its effects over the banking mark-up and interest rates.

In fact, banking mark-up is supposed here as dependent on the rate of technological progress. The explanation for this uncommon specification to the Post-Keynesian models is the assumption that banking mark-up is determined by bank's liquidity preference, in accordance to the so-called structuralist view of money supply endogenity (cf. Pollin, 1991). Changes in a bank's liquidity position,, in turn, is a consequence of a growing demand for finance due to an increasing level of investment expenditures. Since increasing investment is a direct consequence of technological progress, we can use the rate of technological progress as a proxy of the rate at which investment is increasing over time. Thus, when the rate of technological progress receives a positive shock, commercial banks increase the mark-up over the short-term interest rate which is controlled by the Central Bank. The short-term interest rate is used by the Central Bank as the only instrument of monetary policy, whose main goal is supposed to be inflation control.

After presenting the basic structure of the macrodynamic model, it will be simulated in order to determine the dynamic paths of some economic variables. As a first stage in the computer simulation, we will calibrate the parameters of structural equations in order to get a set of trajectories and equilibrium values that are close as possible to the stylized dynamics of capitalist economies. To do that, we will use "true" numerical values for the parameters whenever realiable estimates of these values exist.

However, during the calibration process it is possible (and probable) that for some pamaters there will not be realiable estimates of numerical values. In this case, we will use Samuelson's correspondence principle to set the numerical values required for the computer simulation. According to the correspondence principle, numerical values for the parameters must be set in order to produce a "realistic" dynamic for the model.

The present article has seven sections, including the introduction. In section two we present the basic structure of the model that will be used for the computer simulation. In section three we describe the qualitative behavior of the model in the short and long period equilibrium. In section four we define the standard dynamics against which the study of comparative dynamics will be done. In sections five and six, we will do an impulse-response analysis in order to determine the effects of shocks in the pace of technological progress and in the propensity to save out of profits over some macroeconomic variables. Finally, in section seven, we present some final remarks.

\section{THE BASIC BUILDING BLOCKS OF THE MODEL}

The present model is an attempt to integrate the theoretical structure of growth and distribution models of the "Cambridge School" with the Post Keynesian monetary theory, based in the concept of monetary production economy ${ }^{2}$. The integration proposed is made by means of connecting the pace of technological progress with the banking mark-ups and and interest rates.

Previous attempts at integration between real and monetary aspects of post Keynesian economics were made by Jarsulic (1989), Dutt (1989 and 1992), Dutt \& Amadeo (1993), You (1994), Watanabe (1997) and Lima \& Meirelles (2003). The major difference between our contribution and theirs is the link between banking mark-ups and technological progress.

The present model offers an original contribution to Post Keynesian literature since it incorporates the Shumpteriam vision of the importance of bank credit for the introduction of technological innovations. The 
model also incorporates some other post-keynesian ideas as inflation resulting from class conflict between capitalists and workers, mark-up pricing and technological progress generated by a defensive behavior of firms against the increase of labor costs.

\section{Block 1 - Prices and Production ${ }^{3}$}

Suppose a closed economy without governmental activities, where oligopolistic firms banks produce, by means of a Leontief technology, a homogenous output usable for consumption and investment. Real output is given by:

$$
Q=\min \left[K u_{k} ; L / q\right]
$$

Where: $\mathrm{Q}$ is the level of output, $\mathrm{K}$ is the stock of capital, $u_{k}$ is the ratio between potential output and capital, $L$ is the level of employment and, $q$ is the labor-output ratio.

There are no costs of contracting, training and firing workers, so that there is no such a thing as "labour hoarding". Firms use only the required labour for producing the "planned" level of output. The employment level is determined by:

$$
L=q Q
$$

Due to an oligopolistic market structure, firms have market power to set the prices of their output. Prices are set by means of a mark-up over unitary direct costs. However, in the short-run, the mark-up rate desired by firms may differ from the effective rate of the mark-up. Deviations of effective from desired rate of mark-up may result as an attempt of firms to increase their market-share at expenses of profit margins. In the long run, the mark-up rate must be high enough to generate a "normal" or "conventional" rate of profit. So, a situation where the effective rate of the mark-up is lesser than the desired rate of the mark-up will induce firms to increase prices in order to adjust the former to the latter. Since the wage share is an inverse function of the mark-up rate, we can determine price inflation by the difference between effective wage share and the wage share "desired" by capitalists; i.e, the wage share compatible with the desired rate of mark-up. Formaly, we have:

$$
\hat{\mathrm{P}}=\rho\left[S-S_{f}\right]
$$

Where: $\hat{\mathrm{P}}$ is the proportional rate of variation in prices, $(d P / d t)(1 / P) ; \rho$ is a parameter of sensivity $(0<\rho<1)$ and, $S_{f}$ is the wage share determined by the desired rate of mark-up. Based on Kalecki (1971), the price charged by firms is determined by a mark-up rate, $\mathrm{Z}_{f}$, over primary costs of production. Mathematically we have:

$$
\mathrm{P}=\left(1+\mathrm{Z}_{f}\right) W \cdot q
$$

Where: $W$ is the nominal wage rate.

The wage share desired by capitalists, $S_{f}$, depends inversely on the degree of capacity utilization, expressing Kaldor's idea that firms react to an increase in the demand for their products by an increase in profit margins.

$$
S_{f}=\theta-\varphi u
$$

Where: $\mathrm{Z}_{f}$ is desired rate of mark-up, $\theta$ and $\varphi$ are positive parameters.

\section{Block 2 - Income Distribution.}

Income is generated in the production process so that only productive activities are capable of producing income. In this setting, aggregate income is the sum of wages and profits. Interest payments are seen as a deduction of profits that accrue to productive capitalists. So we have: 


$$
Q=V L+r K
$$

Where: $V \equiv W / P$ is the real wage rate, $W$ is the nominal wage, $\mathrm{P}$ is the level of prices and $r$ is the profit rate defined as the monetary flow of profits divided by the nominal value of capital stock.

Using equations (2), (6), (8) and (9), we find the the following expression for the wage share:

$$
S=V . q
$$

The wage share assumes values between 0 and 1 , more precisely, $0<S<1$; so that the profit share, $m$, can be written as:

$$
m=1-S
$$

The profit rate can be written as a function of the profit share and the degree of capacity utilization. So that:

$$
r=m . u \quad(9)
$$

Where: $u$ it is the degree of capacity utilization, $u=Q / Q^{*} ; Q^{*}=u_{k} K$ is the potential output.

\section{Block 3 - Labor Market}

The proportional rate of variation of nominal wage grows in accordance with the gap between the wage share desired by workers, $S_{W}$, and the effective value of the wage share. The speed of increase in wage inflation is determined by a positive parameter $\lambda$, as demonstrated by the following equation:

$$
\hat{W}=\lambda\left[S_{W}-S\right]
$$

The wage share desired by workers is a direct function of the bargaining power of unions in comparison with that of capitalists. We will suppose that this bargaining power will always increase with the employment rate ${ }^{4}$. Formally we have:

$$
S_{W}=\varepsilon E
$$

Where: $\varepsilon$ is a positive parameter, and $E$ is the employment rate, understood as the ratio between the employment level and the labor force $(L / N)$. The employment rate is related with the degree of capacity utilization as we can see in the following equation:

$$
E=u . k
$$

Where: $k$, is the capital-to-efficiency-labor ratio defined as the ratio between the capital stock, $K$, and supply of labor in efficiency units, $N / q$, as shown by equation (13) below.

$$
k=K /(N / q)
$$

Labor force is supposed to grow at a constant rate sing to a constant rate $\eta$ :

$$
\hat{N}=\eta
$$

\section{Block 4 - Banking Behavior and Monetary Policy}

The short-term interest rate, $i^{B}$, set by the Central Bank, is the only instrument of monetary policy, which main or sole goal is inflation control. We will suppose that the Central Bank increases the nominal short-term interest rate as a reaction to any increase in the rate of inflation ${ }^{5}$. Central Bank follows an interest rate rule given by equation (15):

$$
i^{B}=\phi . \hat{\mathrm{P}}
$$

Where: $\phi$ is a positive parameter that reflects the sensibity of nominal short-term interest rate to changes in inflation rate. 
Commercial banks also have market-power, so that the lending rate of interest is determined by means of a mark-up, $Z_{B}$, over the nominal short-term interest rate, $i^{B}$, which is the opportunity cost for bank lending. So we have:

$$
i=\mathrm{Z}_{B} i^{B}
$$

Banking mark-up here is modeled as being a function of the rate of technological innovation. Banking mark-up is supposed to be a direct function of bank's degree of liquidity preference in accordance to the socalled structuralist view of money and finance (cf. Pollin, 1991). Following Keynes's finance motive for holding money (cf. Keynes, 1973, p.209; Davidson, 2002, pp.97-100), we will assume that increases in the degree of liquidity preference occurs when the economy is carried out of stationary state by means of an increasing level of investment in capital assets. Increasing investment, in turn, is a direct consequence of technological progress, so that the rate of technological progress can be thought of as a proxy to the rate at which investment is increasing over time. In formal terms we have:

$$
\mathrm{Z}_{B}=\mu . \hat{\Gamma}
$$

Where: $\mu$ is a positive parameter, and $\hat{\Gamma}$ is the sensivity of capital accumulation to the rate of technological innovation.

\section{Block 5 - Capital Accumulation and Technological Progress}

The rate by which firms desire to increase their capital stock is described by the following equation ${ }^{6}$ :

$$
\frac{I}{K}^{d}=\alpha+\beta(r-i)+\tau . \hat{\Gamma}
$$

Where: $\frac{I}{K}^{d}$ it is the desired investment by firms as a ratio to capital stock, $\alpha$ is a positive parameter representing the autonomous component of capital accumulation, $\beta$ and $\tau$ are, respectively, positive parameters that measure the sensitivity of investment to the difference between the profit rate, $r$, and the banking rate of interest, $i$, and the sensivity of capital accumulation to the rate of technological innovation, $\hat{\Gamma}$.

The rate of technological innovation, in turn, is defined as being determined by the wage share in income, as we can see in equation (19) below:

$$
\hat{\Gamma}=\psi \cdot S
$$

Where: $\psi$ is a positive parameter that measures the sensivity of the rate of technological innovation to the wage-share.

Technological progress is of labor-saving type, so that its occurrence is associated with a reduction in the labor-output ratio, $q$. The link between wage-share and the rate of technological innovation is due to the fact that one of the main reasons for firms to innovate is to pressure over profitability that came from wage increases. The rate of decrease in labor-output ratio is determined by the following equation:

$$
\hat{q}=-\psi \cdot S
$$

Where: $\hat{q}$ it is the rate of change of labor-output ratio.

As firms operate with excess capacity, they will adjust the level of capacity utilization to the level of effective demand. This means that the rate of profit will be determined by the condition of equalizing the desired rate of capital accumulation to savings as a ratio of capital stock. Assuming that workers spent all they get, and capitalists save a constant share of their profit income, we get the following equation:

$$
\frac{I}{K}=s r
$$


Where: $\frac{I}{K}$ is the growth rate of the capital stock and, $s$ is the propensity to save of capitalists.

\section{THE QUALITATIVE BEHAVIOR OF THE MODEL IN THE SHORT AND IN THE LONG RUN}

In the short run, wage-share and capital-to-efficiency-labor ratio are kept constant. All other dependent variables are determined within the limits of the short run. Output level and capacity utilization are determined in order to assure equalization between the growth rate of capital stock desired by firms and the saving rate of the economy; i.e. $I / K=I^{d} / K$.

Using equations (3), (5), (8), (9), (15), (16), (17), (18), (19) and (21), we can determine the short-run equilibrium value for the degree of capacity utilization, $u^{*}$, as it follows:

$$
u^{*}=\frac{-A \cdot S^{2}+B \cdot S+\alpha}{(s-\beta)(1-S)+C \cdot S}
$$

Being: $A \equiv \beta \mu \phi \psi \rho ; \quad B \equiv \beta \mu \phi \psi \rho \theta+\tau \psi \quad$ and $C \equiv \beta \mu \phi \psi \rho \varphi$. Assuming the usual Keynesian hypothesis that the propensity to save is greater than the propensity to invest, than $C>0$ and we can guarantee that the denominator of this expression is positive. From (22) we can see that the equilibrium level of capacity utilization is a non-linear function of the wage-share. The effect of a change in the wage share over the equilibrium level of capacity utilization is givern by:

$$
\frac{\partial u^{*}}{\partial S}=\frac{D \cdot S^{2}-F \cdot S+G}{[(s-\beta)(1-S)+C \cdot S]^{2}}
$$

Where: $D \equiv A .(s-\beta)-A . C ; F \equiv 2 A(s-\beta) ; G \equiv(B+\alpha)(s-\beta)-\alpha . C$.

As can be seen, the denominator of this expression is always positive for any value of the wage share. In turn, the numerator has ambiguous signs for the numerical values of $D$ and $G . F$ is always positive since it is assumed that propensity to save is bigger than the propensity to invest $(s>\beta)$. We will suppose that $D>0$ and $G>0$. The assumption of $D>0$ implies to assume that the financial sector has a smaller influence over investment decision of firms than the difference between the propensities to save and to invest. So the equilibrium level of capacity utilization will increase with the wage-share for lower values of this values; and it will decrease with wage-share for higher values of this variable, describing an inverted-U curve in the space $\langle u, S>$.

The banking interest rate suffers a joint influence from the rate of technological progress and the nominal short-term interest rate. This last one, in turn, is influenced by the rate of inflation, which also depends on the degree capacity utilization. In sight of this, the interest rate charged by banks is determined by:

$$
i=(\mu \phi \psi \rho) \cdot S^{2}-(\mu \phi \psi \rho \theta) \cdot S+(\mu \phi \psi \rho \varphi) u . S
$$

Substituting the equilibrium level of capacity utilization, given in equation (22), in equation (24), we determine the short-run equilibrium value for banking interest rate, as can be seen in equation (25) below:

$$
i^{*}=\frac{\Psi \cdot S^{3}+\chi \cdot S^{2}+\pi \cdot S}{(s-\beta)(1-S)+C \cdot S}
$$

Where: $\Psi \equiv C(\mu \phi \psi \rho)-(\mu \phi \psi \rho)(s-\beta)-A(\mu \phi \psi \rho \varphi)<0$

$$
\begin{aligned}
& \chi \equiv(\mu \phi \psi \rho \theta)(s-\beta)+B(\mu \phi \psi \rho \varphi)-C(\mu \phi \psi \rho \theta)>0 \\
& \pi \equiv(\alpha \mu \phi \psi \rho \varphi)-(\mu \phi \psi \rho \theta)(s-\beta)>0
\end{aligned}
$$

The equilibrium growth rate of capital sotock, $I^{*} / K$, can be found after using equations (8), (9), (21) e (22): 


$$
\frac{I}{K}^{*}=\frac{s A S^{3}-H S^{2}+M S+s \alpha}{(s-\beta)(1-S)+C S}
$$

Being: $H \equiv s(A+B)$ and $M \equiv s(B-\alpha)$. A time that $A>0$ and admitting that, $0<\alpha<B$, then the parameters $H$ and $M$ are positive, that is, $H>0$ and $M>0$.

The equilibrium value for the rate of profit is determined after substituting equations (8) and (22) in (9). So, we arrive at the following expression:

$$
r^{*}=\frac{A S^{3}-(A+B) S^{2}+(B-\alpha) S+\alpha}{(s-\beta)(1-S)+C S}
$$

In the long run, capital stock, labor force, labor-output ratio, wage-share and capital-to-efficiencylabor ratio are no longer constants, but change through time. For the long-run equilibrium analysis, we will suppose that the degree of capacity utilization, the growth rate of capital stock and banking interest rates are always at their short-run equilibrium values.

From the definitions of the wage share, $S \equiv V q$, and the capital-to-efficiency-labor ratio, $k \equiv K /(N / q)$; the long-run behavior of the system can be analysed by means of the following differential equations:

$$
\begin{aligned}
& \hat{S}=\hat{W}-\hat{\mathrm{P}}+\hat{q} \\
& \hat{k}=\hat{K}+\hat{q}-\hat{N}
\end{aligned}
$$

Where: $\hat{S}=\partial S / S ; \hat{k}=\partial k / k$ and so on.

Substituting to the equations (3), (5), (10), (11), (12) and (20) in equation (28), we can present the proportional variation rate of the wage share as function of capital-to-efficiency-labor ratio, $k$, and of the equilibrium value of the degree of capacity utilization, $u^{*}$; which in turns depends solely on the wageshare, $S$. We have that:

$$
\hat{S}=u^{*}[(\lambda \varepsilon) k-\rho \varphi]-(\lambda+\psi+\rho) S+\rho \theta
$$

Equalizing the proportional growth rate of the wage share to zero and applying the total derivative to the resultant of this expression, is possible to determine the slope of locus $\hat{S}=0$, through the following equation:

$$
\frac{\partial k}{\partial S}=\frac{[\rho \varphi-(\lambda \varepsilon) k]\left(\partial u^{*} / \partial S\right)+(\lambda+\psi+\rho)}{u^{*} \lambda \varepsilon}
$$

The denominator of this expression is always positive for any value of the wage-share, that is, $u^{*}>0$, $\forall 0<S<1$. The derivative of the equilibrium level of capacity utilization to wage share, $\partial u^{*} / \partial S$, is a nonlinear function of $\mathrm{S}$ as determined by equation (22). If we suppose that prices adjust more quicly than nominal wages; then we had that $[\rho \varphi-(\lambda \varepsilon) k]>0$. If we also suppose that $[\rho \varphi-(\lambda \varepsilon) k]\left(\partial u^{*} / \partial S\right)>\lambda+\psi+\rho$; then the slope of locus $\hat{S}=0$ will be negative, $\partial k / \partial S<0$, for low values of the wage share $\left(0<S<S^{*}\right)$ and positive, $\partial k / \partial S>0$, for high values of the wage share $\left(S^{*}<S<1\right)$. Moreover, since $\partial u^{*} / \partial S$ is a quadratic function of wage share, there can be two real roots that satisfy equation $\hat{S}=0$.

We know that $I \equiv \frac{\partial K}{\partial t} \Rightarrow \frac{I}{K} \equiv \hat{K} \equiv s r=s(1-S) u$. When substituting this equation together with equations (14) and (20) in equation (29); we can show the proportional variation rate of capital-to-efficiencylabor ratio, $\hat{k}$, as a function of the wage-share, $S$, as we can see in equation (32):

$$
\hat{k}=\frac{s A \cdot S^{3}+\Omega \cdot S^{2}+\Sigma . S+\Lambda}{(s-\beta)(1-S)+C . S}
$$


Where: $\Omega \equiv C \psi-H-\psi(s-\beta)<0 ; \Sigma \equiv J+\eta C+\psi(s-\beta)-\eta(s-\beta)>0 ; \Lambda \equiv s \alpha+\eta(s-\beta)>0$ and $\eta$ is the exogenous growth rate of the labor force ${ }^{7}$.

Given these restrictions to the values of the parameters, it is possible to divide the distributive domain in two regions that we will call as PL (Profit-Led regime) and WL (Wage-Led regime). In region PL, defined in the interval $0<S<S^{*}$, an increase in wage-share will result in a decrease in the level of capacity utilization and profit-rate. The decrease in $u$ and $r$ more than off-set the decrease of the banking interest rate, so that the rate of capital accumulation rate decreases as a result of an increase in $S$. On the other hand, in region WL, defined in the interval $S^{*}<S<1$, an increase in wage-share will result in a increase in the level of capacity utilization and profit-rate, since the increase in the level of capacity utilization more than off-set the reduction in the profit-share. As a result of this chanfes, the rate of capital accumulation increases with $S$.

The Jacobian Matrix of the system composed by equations (30) and (32) is given by:

$$
\begin{aligned}
J_{11} & \equiv \partial \hat{S} / \partial S=\left(\partial u^{*} / \partial S\right)(\lambda \varepsilon \cdot k-\rho \varphi)-(\lambda+\psi+\rho) \\
J_{12} & \equiv \partial \hat{S} / \partial k=\lambda \varepsilon \cdot u^{*}>0 \\
J_{21} & \equiv \partial \hat{k} / \partial S=\left[\partial\left(I^{*} / K\right) / \partial S\right]+\psi \\
J_{22} & \equiv \partial \hat{k} / \partial k=0
\end{aligned}
$$

Due to the existence of non-linearities in the model and to the fact that the analysis that we aim to do in this section is merely qualitative, there are diverse possible long-run equilibrium configurations in the space $(k-S)$. So, we choose to analyse just one of these possible long-equilibrium configurations, more precisely, the one that has an unstable equilibrium of saddle-path type in region PL and stable equilibrium in the region WL.

Since we are supposing that prices adjust more quickly than nominal wages and remembering that in region PL, $\partial u^{*} / \partial S<0, J_{12}>0$ and $J_{22}=0$; the nature of the equilibrium in this region will depends on signal of $J_{11}$. The analysis of this region shoes us that if $\left(\partial u^{*} / \partial S\right) \cdot[(\lambda \varepsilon) k-\rho \varphi]>(\lambda+\psi+\rho)$, the trace of the Jacobian matrix will be positive, $\operatorname{Tr}|J|>0$. As in this region, $\partial\left(I^{*} / K\right) / \partial S>0$, what makes $J_{21}>0$ for all value of the wage share in the interval between 0 and 1 ; then $\operatorname{Det}|J|<0$. In this case, the dynamic system will have an unstable equilibrium of saddle-path type. However, if $\left(\partial u^{*} / \partial S\right) \cdot[(\lambda \varepsilon) k-\rho \varphi]<(\lambda+\psi+\rho)$, then the trace of the Jacobian matrix will be negative, $\operatorname{Tr}|J|<0$, and since the determinant of the Jacobian matrix continues to be being negative, Det $|J|<0$, then the system will not have an equilibrium.

In analyzing region WL we see that in this region $\partial u^{*} / \partial S>0$, the proportional variation of the wageshare with regard to itself will be negative, $J_{11}<0$; and since $J_{22}=0$, the trace of the Jacobian matrix will be also negative, $\operatorname{Tr}|J|<0$. Since $J_{12}>0, \forall 0<S<1$, the nature of the equilibrium in this region will depend on the signal of $J_{21}$. We assume that $\partial\left(I^{*} / K\right) / \partial S<0$ for the values of the wage share that lies in this region; if $\partial\left(I^{*} / K\right) / \partial S>\psi$ then $J_{21}<0$ and the determinant of the Jacobian matrix will be greater than zero, $\operatorname{Det}|J|>0$ and the system will have a stable equilibrium. However, if $\partial\left(I^{*} / K\right) / \partial S<\psi$ then $J_{21}>0$, and the determinant of the Jacabian Matrix will be negative, Det $|J|<0$, and the system will have no equilibrium at all.

Given that, diverse combinations exist in the space $(k-S)$, that generate some type of equilibrium. Amongst these combinations, figure 1 below shows us one example where there is an unstable equilibrium of saddle-path type in region PL; and a stable equilibrium in region WL. Since throughout the distributive domain we have $J_{12}>0$ and $J_{22}=0$, the determination of this configuration it will depend on the signals of 
$J_{11}$ and $J_{21}$ that, in turn, depends on relative bargaining power of capitalists and workers, the "flexibility" of prices and nominal wages; the relative importance of the difference between the propensity to save and the propensity to invest viz-a-viz the financial variables; the strenght of technological innovation amongst other factors.

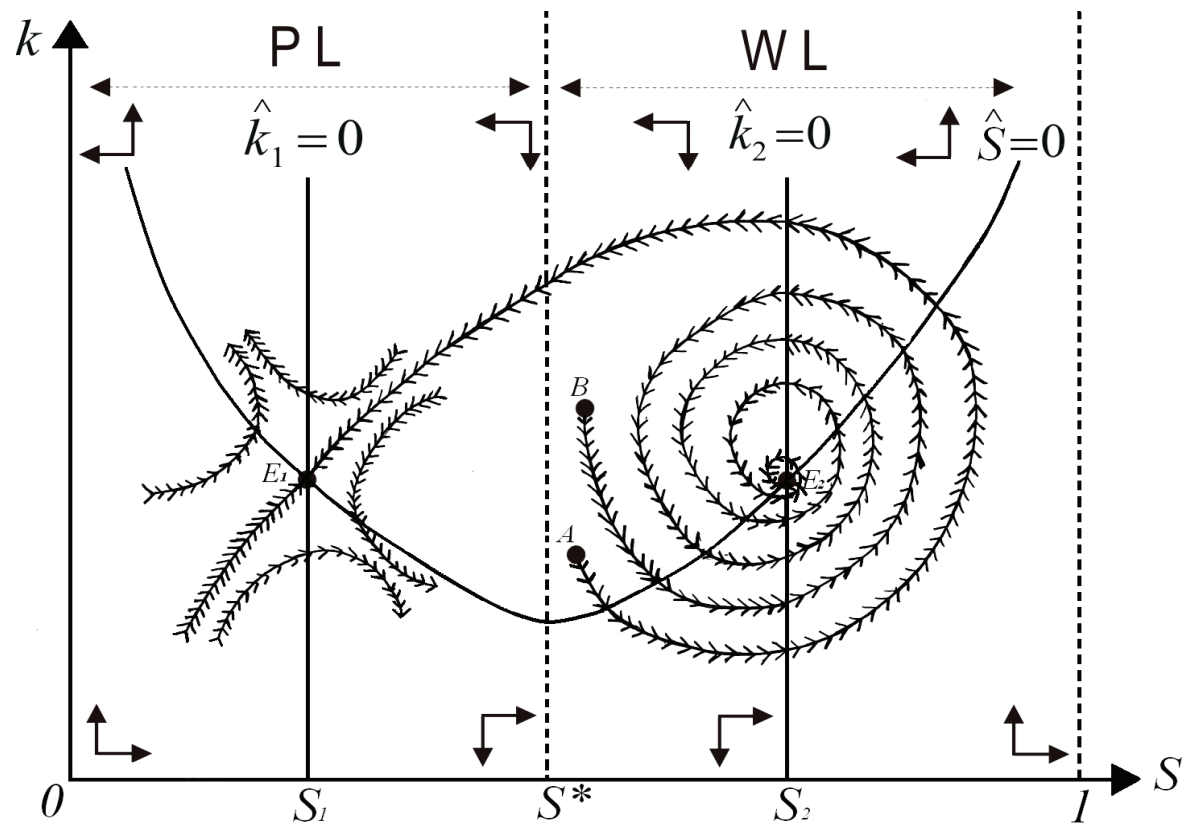

\section{FIGURE 1: A POSSIBLE LONG-RUN EQUILIBRIUM CONFIGURATION}

We will assume that in region PL, $J_{11}>0$, therefore we consider the sensivity of prices bigger than of nominal wages and that, the influence of the product between the degree of capacity utilization and the parameters that define the real wage rate is bigger than the sum of the parameters of the equations of the rate of technological innovation, the level of prices and the nominal wages. Moreover, we assume that $J_{21}>0$, that is, that the difference between the propensity to save and to invest is bigger than of the product of all parameters of the banking interest rate equation.

For region WL we establish that $J_{11}<0$ and $J_{21}<0$. The negative signal of the first element of the Jacobian matrix, $J_{11}$, can be easly checked. It is enough to remember that in this region $\partial u^{*} / \partial S>0$. The negative signal of the second element requires that we establish, in first place, that the difference between the propensity to save and to invest is bigger than the product of all the parameters of the banking interest rate eqaution. In second place, it is necessary to assume that the sensivity of accumulation rate to changes in wage-share is bigger than the sensivity of technological innovation rate to changes in this variable.

Analyzing the dynamic behavior of the system in the space $(k-S)$, we see that there is sub-region inside region WL where state variables will exhibit damped fluctuations around equilibrium point $\mathrm{E}_{2}$. As it can be observed by the trajectory that leaves point $\mathrm{B}$.

This zone, whose dynamics is characterized by dampened fluctuations, we will call the zone of stability and its complement will be called the instability zone. In the event that the economy is moving inside the instability zone, its behavior will be explosive except if it starts just on point $\mathrm{A}$. If this happens to be the case, the economy will converge to the equilibrium point $\mathrm{E}_{1}$, in region PL.

The saddle-path trajectory is the one that separetes the zone of stability from the zone of instability. In fact, any trajectory that begins above the one represented by the saddle-path will converge to the equilibrium point in WL region; and any trajectory that begins below that one will generate an explosive dynamics. 


\section{DEFINING THE STANDARD DYNAMIC TRAJECTORY ${ }^{8}$}

The initial point of the analysis of comparative dynamics is the definition of the standard dynamic trajectory against which other trajectories will be compared. To do that, we have to define the initial values for all the parameters of the model, trying to set values that are 'founded' in empirical evidence about the magnitude of these parameters in the real world. Table 1 below presents the parameters with its respective values and the function that they play in the model.

TABLE 1: PARAMETERS AND VALUES IN STANDARD DYNAMIC TRAJECTORY

\begin{tabular}{|c|c|c|}
\hline PARAMETERS & VALUE & DESCRIPTION \\
\hline$\alpha$ & 0.01 & Autonomous propensity to invest or "animal spirits" of investors. \\
\hline$s$ & 0.80 & Propensity to save of capitalists. \\
\hline$\beta$ & 0.75 & $\begin{array}{l}\text { Coefficient that measures the sensivity of desired investment to the difference between the } \\
\text { profit rate and the banking interest rate. }\end{array}$ \\
\hline$\tau$ & 0.25 & $\begin{array}{l}\text { Coefficient that measure the sensivity of desired investment to variations in the rate of } \\
\text { technological progress. }\end{array}$ \\
\hline$\psi$ & 0.03 & $\begin{array}{l}\text { Coefficient that measures the sensivity of the rate of technological progress with regard to } \\
\text { variations in the wage share. }\end{array}$ \\
\hline$\rho$ & 1.10 & $\begin{array}{l}\text { Coefficient that sensivity of price inflation with relation to the difference between the } \\
\text { effective wage share and the one determined by the desired mark-up rate of the firms. }\end{array}$ \\
\hline$\theta$ & 0.40 & Parameter that measures the autonomous component of the desired wage-share by firms. \\
\hline$\varphi$ & 0.70 & $\begin{array}{l}\text { Coefficient that measures the influence of the degree of capacity utilization over the } \\
\text { wage-share desired by firms. }\end{array}$ \\
\hline$\lambda$ & 0.50 & $\begin{array}{l}\text { Coefficient that measures the sensivity of wage inflation to the difference between the } \\
\text { wage-share desired by workers and the effective wage-share. }\end{array}$ \\
\hline$\varepsilon$ & 0.025 & $\begin{array}{l}\text { Coefficient that measures the sensitivity of the wage-share desired by workers to the } \\
\text { employment rate. }\end{array}$ \\
\hline$\eta$ & 0.01 & Population growth rate. \\
\hline$\phi$ & 1.50 & $\begin{array}{l}\text { Coefficient that measures the sensivity of the nominal short-term interest basic rate to the } \\
\text { changes in the rate of inflation. }\end{array}$ \\
\hline$\mu$ & 1.15 & $\begin{array}{l}\text { Coefficient that measures the influence of the rate of technological progress over banking } \\
\text { interest rate. }\end{array}$ \\
\hline
\end{tabular}

Based on Kaldor (1993), the propensity to save of the capitalists, $s$, was assumed to be $0.8^{9}$. We assume that this economy presents a population growth rate, $\eta$, on the order of $1 \%$ (or 0.01 ) per year. We also assumed that the sensivity of the short-term interest rate with the rate of inflation, $\phi$, is 1.50 , an estimative based on econometric evidence for the Brazilian economy. (Blanchard, 1999, p. 359)

However, many parameters of the model have no numerical values founded on empirical evidence, therefore being free parameters. However, it is possible to infer reasonable (in economic terms) values for these parameters. To do that is enough to isolate its effects by means of the assumption that the other parameters of the equation being analysed assume a zero value. 
For example, we are assuming a value for the autonomous part of the investment function of $\alpha=0.01$. The choice of this value can be justified by the fact that when we set the values of parameters $\beta$ and $\tau$ equal to zero; equation (18) that determines the desired rate of capital accumulation shows that firms desire a growth rate of capital stock of $1 \%$ per period, a very reasonable number.

Following this exactly procedure, we determine the values for the other parameters. In fact, for the parameter that describes the sensivity of the rate of technological progress with relation to the wage-share, $\psi$, we assume a maximum limit of growth rate of labour productivity of 3\% per-period. Assuming a $10 \%$ difference between the wage-share desired by workers and the effective value of the wageshare $\left(S_{W}-S=0.1\right)$, then wage inflation will be of $5 \%$, what suggests the value $\lambda=0.5$.

Once we have set the parameters values that produces a satisfactory equilibrium, and defining the initial conditions of the system as follows: $k[0]=0.5$ and $S[0]=0.75$, is possible to analyze the behavior of some macroeconomic variables. For this, we analyze time-behavior of the level of capacity utilization, $u$; the rate of capital accumulation, $I / K \equiv d K / K$; profit rate, $r$; and finally, the banking interest rate, $i$.

Figure 2 shows the time-path of the degree of capacity utilization and the rate of capital accumulation. We can see that the degree of capacity utilization starts at a value of $37.96 \%$ and increases during twenty periods, reaching a maximum value of $94 \%$. Then it decreases to its steady-state value of $71.98 \%$. It is important to notice that the level of capacity utilization never reach $100 \%$, so that firms always operate with excess capacity. The rate of capital accumulation, in turn, starts at a value of $2.53 \%$ and increases during next 45 periods, reaching its steady-state value of $17.73 \%$ per-period.

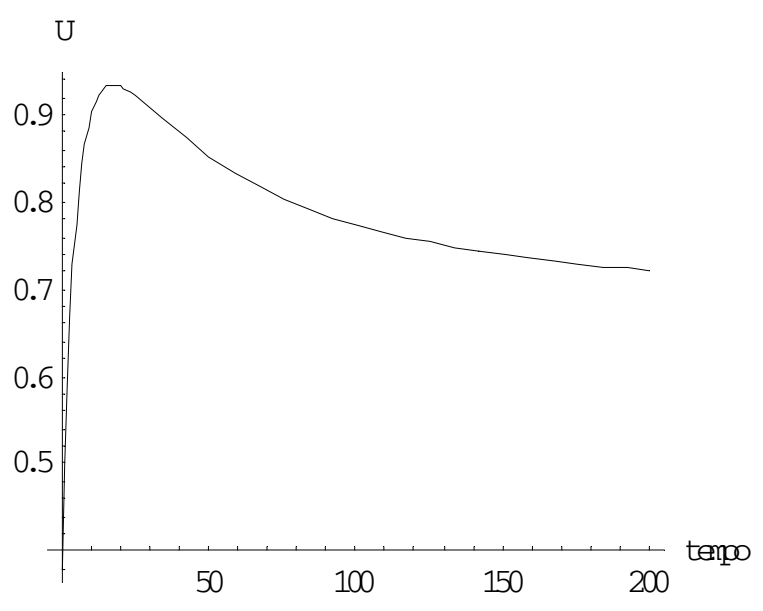

(a) Capacity Utilization $(u)$

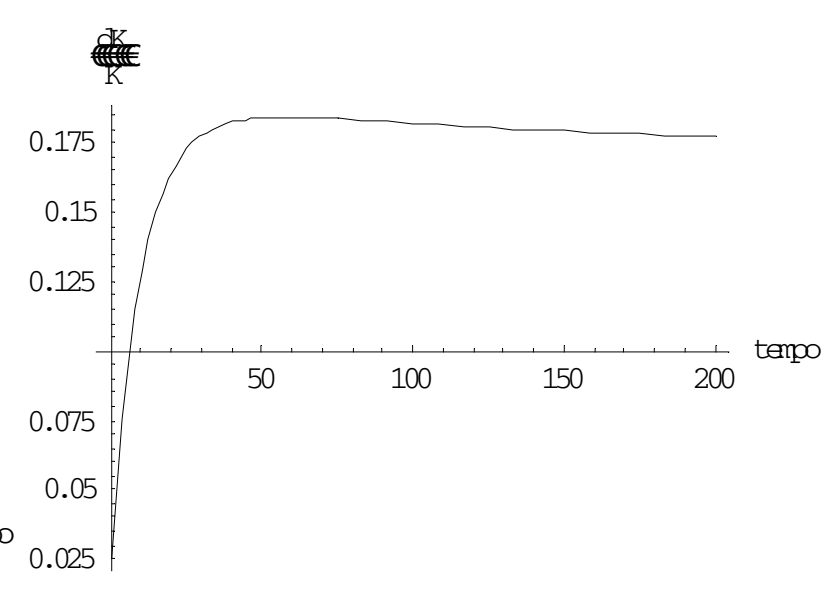

(b) Capital Accumulation $(d K / K \equiv I / K)$ FIGURE 2: STANDARD DYNAMICS FOR $(u)$ AND $(d K / K)$

The trajectories for the profit rate and the banking interest rate are shown in figure 3. As we can see, the profit rate, initiating at a $3.16 \%$ value, grows at decreasing rates until reaching its steady-value $22.16 \%$ in period 46. For its turn, the banking interest rate starts at an initial value of $24.96 \%$, decreasing during the entire simulation period, until reaches its steady-state value of $1.93 \%$. 


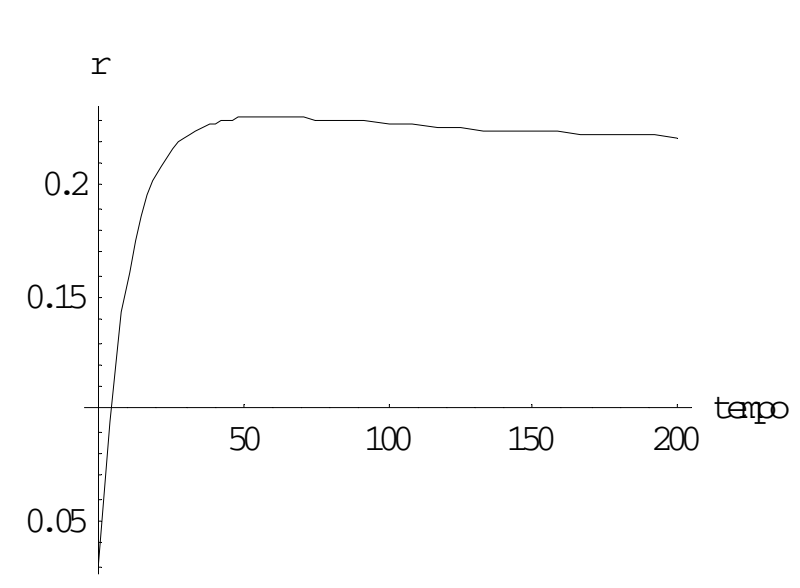

(a) Profit rate $(r)$

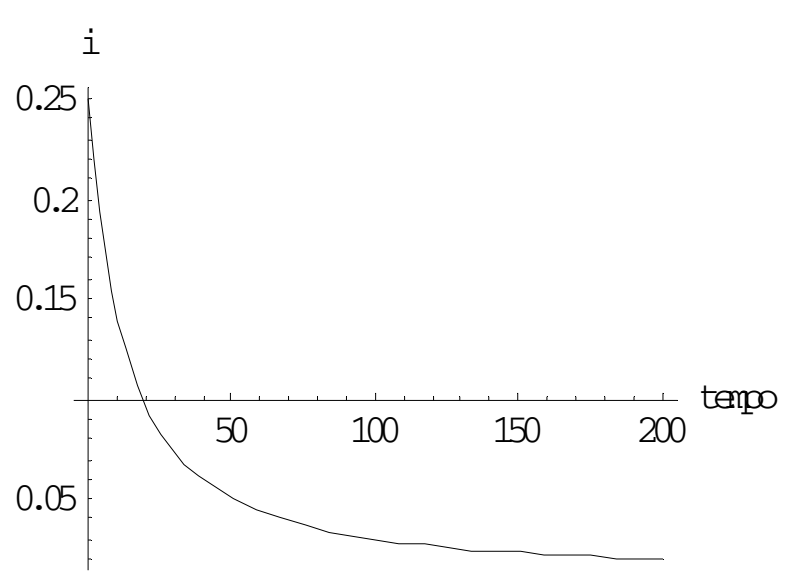

(b) Banking interest rate $(i)$

FIGURE 3: THE STANDARD DYNAMICS FOR $(r)$ AND $(i)$

After defining the set of parameters that generate the standard dynamics, we will now carry through a impulse-response exercise. In other words, we will modify the numerical values for two key parameters for the study in course, that is: the parameter that determines the rate of technological progress and the value of capitalists's propensity to save.

\section{TEST OF IMPULSE- RESPONSE: THE INFLUENCE OF TECHNOLOGICAL SHOCKS}

The first test of impulse-response will be made to analyze the impact of technological shocks on the dynamic trajectories of the economic system in study. In effect, we will go to raise in $33 \%$ (of 0.03 for 0.04 ) the sensivity of the technological parameter and to check the impact that this shock has over the dynamics of the main macroeconomic variables in study.

Figure 4 below presents the comparative dynamics of the degree of capacity utilization and the rate of capital accumulation for the old value (red line) and new (blue line) value of sensivity of the technological progress, $\psi$. Immediately, one perceives that the technological shock diminished the initial value of the degree of capacity utilization from $37.96 \%$ to $18.10 \%$ ( $19.86 \%$ reduction).

With regard to the dynamic trajectory of $u$, we can see that the initial impact of the technological shock is substantially different from its long-term effects. In fact, the equilibrium value of capacity utilization raises from $73.53 \%$ to $75.87 \%$.

The dynamics of capital accumulation also changes due to the technological shock. In fact, the initial value of the rate of capital accumulation was of $2.53 \%$ before the shock and reduces to $1.21 \%$ after the shock. With regard to its dynamic path, one perceives that initially the rate of capital accumulation assumes values lower than the ones observed in the standard dynamic path. However, after period 27, the new trajectory generated for the shock had higher values for the rate of capital accumulation than standard path. In numerical terms, the new equilibrium value of the rate of capital accumulation is nearby $17.97 \%$, compared to an initial value of $17.89 \%$. This exercise shows us that the rate of capital accumulation is almost insensitive to technological shocks. 


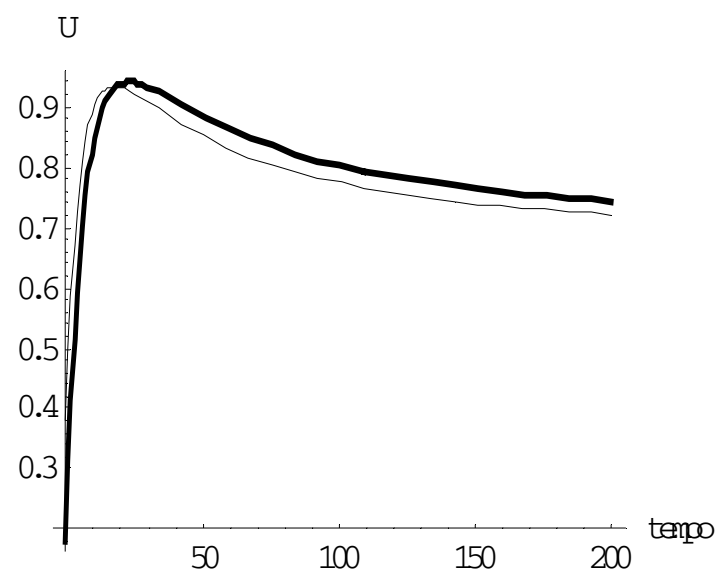

(a) Degree capacity utilization $(u)$ where $(\psi=0.03)$ and $\underbrace{(\psi=0.04)}_{\text {"BOLD-LINE" }}$

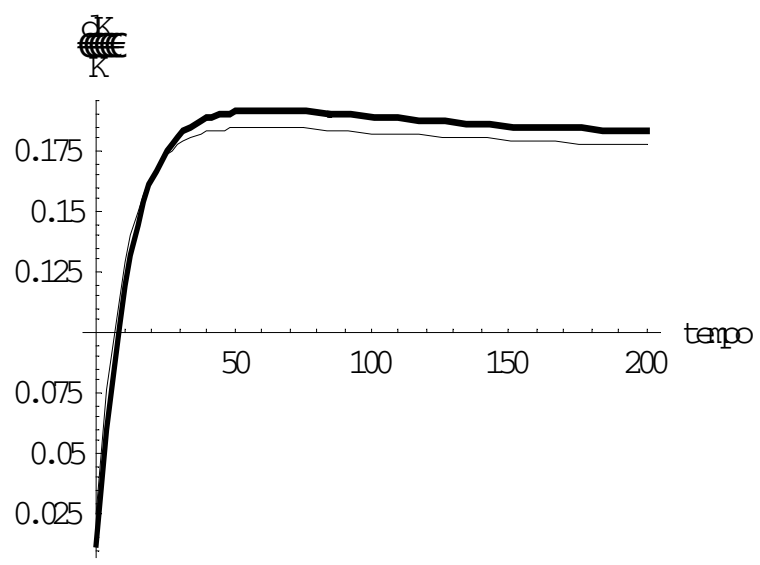

(b) Capital Accumulation $(d K / K \equiv I / K)$ where $(\psi=0.03)$ and $\underbrace{(\psi=0.04)}_{\text {"BOLD-LINE" }}$

FIGURE 4: IMPACT OF THE TECHNOLOGICAL SHOCK OVER $(u)$ AND $(d K / K)$

The trajectories of the profit rate and the banking interest rate are shown in figure 5. Looking first at the profit rate, we see that the technological shock reduces the initial value of $3.16 \%$ to $1.51 \%$. Moreover, the behavior the profit rate shows that the shot-term effect of a technological shock is to reduce the rate of profit.

However, in period 27, an inversion between the two trajectories occurs. After the technological shock, profit rate reaches an equilibrium value superior of $31.09 \%$, much higher than the equilibrium value of this variable before the shock. Thus we can conclude that the sensivity of profit rate to the rate of technological progress is very high. In fact, the elasticity of the profit rate to the rate of technological progress is of 1.3 , implying that a $1 \%$ increase in the sensivity of the technological progress generates an increase of $1.3 \%$ in the profit rate.

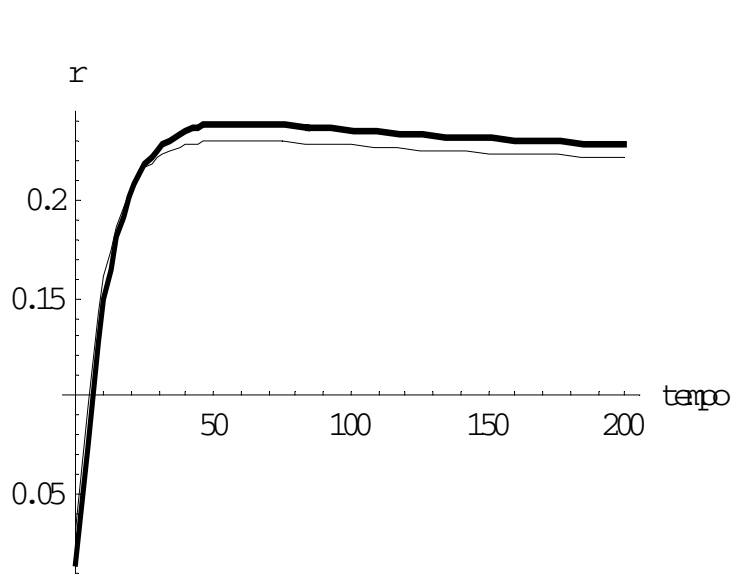

(a) Profit rate $(r)$ where

$$
(\psi=0.03) \text { and } \underbrace{(\psi=0.04)}_{\text {"BOLD-LINE" }}
$$

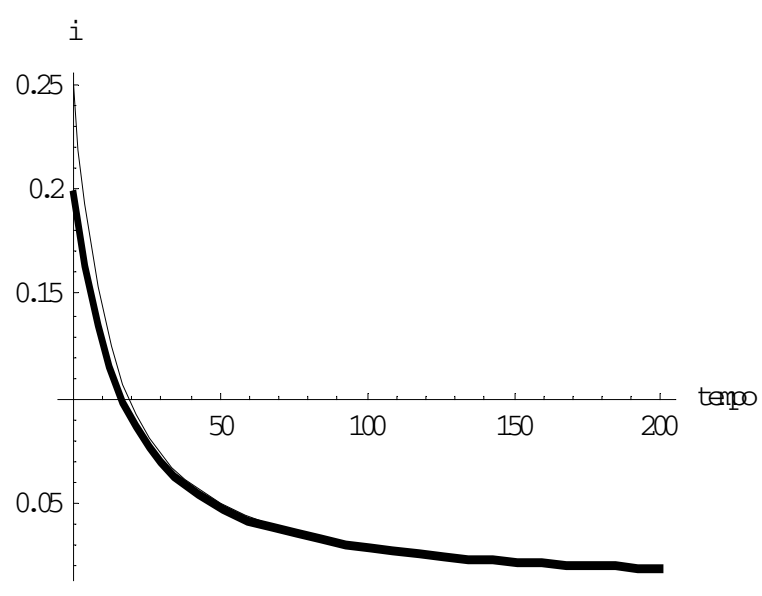

(b) Banking interest rate $(i)$ where $(\psi=0.03)$ and $\underbrace{(\psi=0.04)}_{\text {"BOLD-LINE" }}$

FIGURE 5: IMPACT OF THE TECHNOLOGICAL SHOCK OVER $(r)$ AND $(i)$ 
In figure 5, one can also perceive that the initial value of the banking interest rate had been reduced from $24.96 \%$ to $19.75 \%$. However, the steady-state value of the banking interest rate after the shock is almost equal to the one prevailing before the shock.

The analysis done is summarized in table 2. As we can see in this table, almost all macroeconomic variables under analysis are inelastic to changes in the sensivity paramater of technological progress, with exception the sole exception of profit rate that had an elasticity equal to 1.3.

TABLE 2: INFLUENCE OF THE TECHNOLOGICAL SHOCK $(\psi=0.4$ or $+33 \%)$

\begin{tabular}{lcccc}
\hline \multicolumn{1}{c}{ Variable } & $u$ & $I / K$ & $r$ & $i$ \\
\hline \hline Standard Value & 0.7353 & 0.1789 & 0.2236 & 0.0222 \\
Final Value & 0.7587 & 0.1847 & 0.3209 & 0.0211 \\
Percentile Variation & $3.18 \%$ & $3.24 \%$ & $43.51 \%$ & $-0.95 \%$ \\
Elasticity & $<1$ & $<1$ & $>1$ & $<1$ \\
\hline \hline
\end{tabular}

Moreover, we can see in table 2 that the degree of capacity utilization, $u$, the rate of capital accumulation, $I / K$, and the profit rate, $r$, are positively correlated with the parameter, $\psi$. On the other hand, the banking interest rate, $i$, presents a negative correlation to this parameter.

\section{TEST OF IMPULSE-RESPONSE: CHANGES IN THE PROPENSITY TO SAVE OF CAPITALISTS}

The second and the last experiment consist of analyzing the effect of a $1 \%$ increase in the propensity to save of capitalists. Such increase can be seen, amongst other factors, as a defensive action of capitalists to an increase in uncertainty.

Figure 6 shows the effects of a 1\% increase in propensity to save over the degree of capacity utilization and the rate of capital accumulation. As a response to this shock, the initial value for the level of capacity utilization is reduced from $37.96 \%$ to $35.90 \%$. One can also see that until period 10 , there is no difference between the standard path and the new one. However, after this period, the two trajectories start to diverge.

In effect, the trajectory that describes the dynamics of the capacity utilization for the new value of the propensity to save more reaches its maximum value around $83.75 \%$, in contrast to $93.87 \%$ of the standard path. After that, capacity utilization decreases to its new steady-state equilibrium of $65.43 \%$, in constrast to a value of $73.53 \%$ in the standard path. So we can conclude thar a $1 \%$ increase propensity to save generated a reduction of $11.02 \%$ in the degree of capacity utilization.
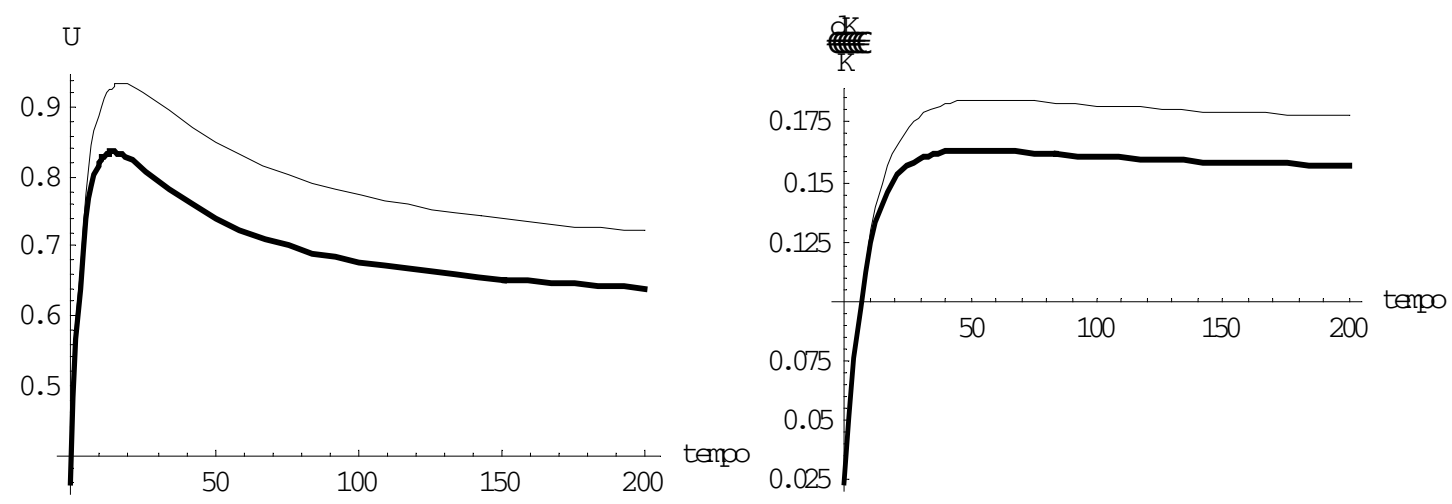
a) Degree of capacity utilization $(u)$ where $(s=0.8)$ and $\underbrace{(s=0.808)}_{\text {"BOLD-LINE" }}$
(b) Capital accumulation $(d K / K \equiv I / K)$ where $(s=0.8)$ and $\underbrace{(s=0.808)}_{\text {BOLD-LINE" }}$

FIGURE 6: THE INFLUENCE OF THE PROPENSITY TO SAVE OVER $(u) \operatorname{AND}(d K / K)$ 
In turn, the dynamics of the rate of capital accumulation described in Figure 6 shows that an increase in propensity to save almost has no effect over the initial value of the rate of capital accumulation. In fact, the initial value of the rate of capital accumulation is reduced from $2.53 \%$ in the standard path to only $2.42 \%$ in the new trajectory. Moreover, the time path of capital accumulation is little affected by the increase of the propensity to save until period 10. After this period, both trajectories start to diverge. In fact, the new steadystate value for the rate of capital accumulation is $15.85 \%$, muche lower than the $17.89 \%$ value for the standard path.

Figure 7 below describes the dynamics of the profit rate and the banking interest rate after a $1 \%$ increase of the propensity saving of capitalists. Thus, the increase of propensity to save reduces the initial value of the profit rate from $3.63 \%$ to $2.99 \%$. We can also see that the behavior of the trajectories for the profit rate remains similar until period 10. After that, we verify that profit rate is much lower in the new path (the one with a higher propensity to save) than in the standard path. In other words, an increase in the propensity to save of capitalists produced a huge of profit rate in the long-term. In fact, the steady-state value of profit rate was reduced from $22.36 \%$ to $19.62 \%$.

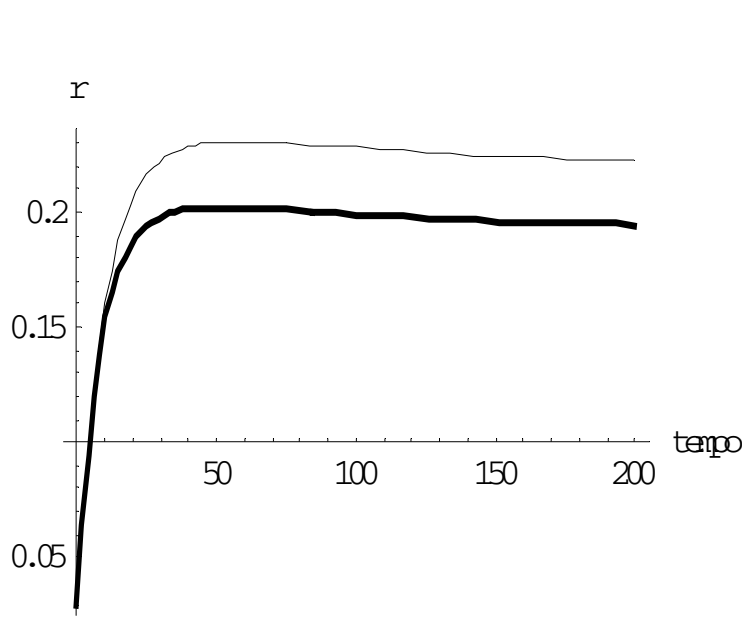

(a) Profit rate $(r)$ where $(s=0.8)$ and $\underbrace{(s=0.808)}_{\text {"BOLD-LINE" }}$

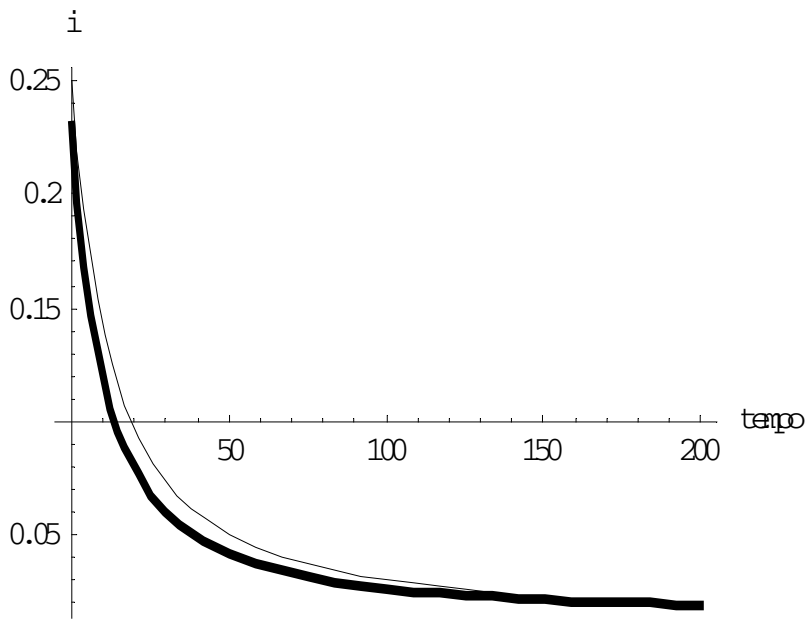

(b) Banking interest rate $(i)$ where

$$
(s=0.8) \text { and } \underbrace{(s=0.808)}_{\text {BOLD-LINE" }}
$$

FIGURE 7: THE INFLUENCE OF THE PROPENSITY TO SAVE OVER $(r)$ AND $(i)$

The banking interest rate, after the increase in the propensity to save, assumes since the beginning a trajectory that differs from the standard. Its initial value falls from $24.96 \%$ to $23.00 \%$ after the change of the propensity to save and, through time, it starts to fall, showing values that are smaller than ones presented in the standard path. However, in the long term, both paths converge to almost the same steady-state value for the banking interest rate.

Table 3 sumarizes the results of the exercizes made above. As we can see, all macroeconomic variables in study have an elasticity to changes in the propensity to save of capitalists bigger than - 1 . In fact, a $1 \%$ increase in the propensity to save of capitalists generated a significant reduction in the degree of capacity utilization, rate of capital accumulation, profit rate and, in lesser intensity, the banking interest rate. 
TABLE 3: THE INFLUENCE OF THE PROPENSITY TO SAVE $(s=0.808$ or $+1 \%)$

\begin{tabular}{lcccc}
\hline \hline \multicolumn{1}{c}{ Variable } & $u$ & $I / K$ & $r$ & $i$ \\
\hline \hline Standard Value & 0.7353 & 0.1789 & 0.2236 & 0.0222 \\
Final Value & 0.6543 & 0.1585 & 0.1962 & 0.0220 \\
Percentile Variation & $-11.02 \%$ & $-11.37 \%$ & $-12.25 \%$ & $-1.08 \%$ \\
Elasticity & $>1$ & $>1$ & $>1$ & $>1$ \\
\hline \hline
\end{tabular}

An interestining result of our analysis is the theoretical possibility of the occurrence of the paradox of the thrift suggested by Keynes (1936) in the General Theory and later extended for the long run by Joan Robinson (1960). Observing table 3 it is easy to see that a $1 \%$ increase in the propensity to save generates a reduction of $12.25 \%$ in the profit rate. Since savings as a ratio to the stock of capital, as defined by equation (21), is the product between the propensity to save of capitalists and the profit rate; an increase in the propensity to save will produce a huge reduction in total savings.

\section{FINAL REMARKS}

The objective of the present paper was to analyze the long-run features of a Post Keynesian macroeconomic dynamic model by means of a numerical analysis carried through computational simulation. For this, we first show the structure of a macro-dynamic model of third generation that incorporates some elements of Post Keynesian monerary theory, especially the interdependence between the real and monetary factors for the determination long-run dynamics of the system.

The central element that differentiates the present model from other Post Keynesian models is the way that money exerts its influence over the macroeconomic variables in study. This influence is given through the link between the rate of technological progress and the banking rate of interest. We supposed that an increase in the rate of technological progress increases the banking interest rate as as result of the increase in banks liquidity preference. Monetary policy is also important for the results of the model. We supposed that the Central Bank conducts monetary policy in order to reach a target for the real rate of interest, so that money supply is endogenous.

The results of the numerical simulation of the model had show the existence of a paradox of thrift, since an increase in the propensity to save of capitalists caused a reduction of aggregate saving rate. More specifically, a $1 \%$ increase in the propensity to save of capitalists caused a significant fall in the profit rate ($12.25 \%$ ), generating a net reduction in aggregate saving rate.

Finally, results of simulation suggest that for the maintenance of macroeconomic stability, a low propensity to save is more important than a high rate of techonogical innovation. 


\section{REFERENCES}

CARVAlHO, F. C. Mr. Keynes and the Post Keynesians: principles of macroeconomics for a monetary production economy. Edward Elgar: Aldershot, 1992.

CARVALHO, L. D. Endogeneidade Monetária, Crescimento Econômico e Distribuição de Renda: uma Integração Teórica da Macro-Dinâmica Pós-keynesiana. Master Dissertation, Federal University of Paraná - UFPR -, Curitiba, Brazil, 2005.

BLANCHARD, O. Macroeconomia: Teoria e Política. 1. ed. Rio de Janeiro: Campus, 1999.

DAVIDSON, P. Money and the Real Word. MacMillan: London, $2^{\circ}$ ed., 1978.

. Financial Markets, Money and the Real World. Edward Elgar: Aldershot, 2002.

DUTT, A. K. Accumulation, distribution and inflation in a Marxian/Post keynesian model with a rentier class. Review of Radical Political Economics, 21(3): 18-26, 1989.

. Expectations and Equilibrium: implications for Keynes, the Neo-Ricardian Keynesians, and the Post-Keynesians. Journal of Post Keynesian Economics, vol. 14, nº 2, 1992.

. On the Long-run Stability of Capitalist Economies: Implications of a Model of Growth and Distribution. In A. K. Dutt (org.), New Directions in Analytical Political Economy, Aldershot: Edward Elgar, 1994.

DUTT, A. K.; AMADEO. E. J. A Post-Keynesian theory of growth, interest and money. In The Dynamics of the Wealth of Nations: Growth, Distribution and Structural Change. M. BARANZINI \& G. C. HARCOURT (Eds.). St. Martins's Press, New York, 1993.

FIOCCA, D. A oferta de moeda na macroeconomia Keynesiana. Editora Paz e Terra, São Paulo, 2000.

HANSEN, L.; HECKMAN, J. The empirical foundations of calibration. Journal of Economic Perspectives, vol. $10, \mathrm{n}^{\circ} 1,1996$.

HARROD, R. An Essay in Dynamic Theory. Economic Journal. Vol. 49, mar., 1939.

HICKS, J. Mr. Keynes and the classics: a suggested interpretation. Econometrica, 1937.

JARSULIC, M. Endogenous credit and endogenous business cycle. Journal of Post Keynesian Economics, v. 12, n. 1, p. 35-47, 1989.

KALDOR, N. A Model of Economic Growth. The Economic Journal. Vol. 67, 1957

KALDOR, N. Marginal Productivity and the Macroeconomic Theories of Distribution. In Post Keynesian Theory of Growth and Distribution. Carlo Panico; Neri Salvadori, University Press, Cambridge, 1993.

KALECKI, M. Selected Essays on the Dynamics of the Capitalist Economy. Cambridge University Press, 1971.

KEYNES, J.M. The General Theory of Employment, Interest and Money. Macmillan Press: Cambridge, 
1936.

KEYNES, J.M. Alternative Theories of the Rate of Interest In: The Collected Writings of John Maynard Keynes, Vol. XIV, 1973.

KREGEL. J. A. Hamlet without the Prince: Cambridge Macroeconomics without Money. American Economic Review. 1985.

LIMA. G. T. Progresso Tecnológico Endógeno, Crescimento Econômico e Distribuição de Renda. In LIMA, G. T, SICSÚ, J, DE PAULA, L. F (orgs). Macroeconomia Moderna: Keynes e a Economia Contemporânea. Campus: Rio de Janeiro, 1999.

LIMA, G. T.; MEIRELlES, A. J. Mark-up Bancário, Conflito Distributivo e Utilização da Capacidade Produtiva: Uma Macrodinâmica Pós-Keynesiana. Revista Brasileira de Economia. Jan. mar, 2003.

MARX, K. O Capital. Civilização Brasileira, Rio de Janeiro, 1971.

NELSON, R.; WINTER, S. An Evolutionary Theory of Economic Change. Harvard University Press: Cambridge, 1982.

PASINETI, L. Rate of Profit and Income Distribution in Relation to the Rate of Economic Growth. Review of Economic Studies, Vol. 29, 1962.

POLLIN, R. Two Theories of Money Supply Endogenity: some empirical evidence. Journal of Post Keynesian Economics. Vol. 13, N. 2, Sping, 1991.

ROBINSON, J. The Theory of Income Distribution. Collected Economic Papers, Vol II: Basil Blackwell: Oxford, 1960.

ROWTHORN, R. Demand, Real Wages and Economic Growth. Thames Papers in Political Economy. Fall, 1981.

RUNDE, J. Keynesian Uncertainty and Liquidity Preference. Cambridge Journal of Economics, 18, 1994.

. Risk Uncertainty and Bayesian Decision Theory: a Keynesian view. In DOW, S; HILLARD, J. (org.). Keynes, Knowledge and Uncertainty. Edward Elgar: Aldershot, 1995.

SAMUELSON, P. Fundamentos da Análise Econômica. Abril Cultural: São Paulo (1983) [original edition: 1945]

SCHUMPETER, J. The Theory of Economic Development. $2^{\mathrm{a}}$ ed. Nova York: Harper \& Brothers, 1934 [1912].

WATANABE, K-I. An Endogenous Growth Model with Endogenous Money Supply: Integration of PostKeynesian Growth Models. Banca Nazionale Del Lavoro Quarterly Review, 200, mar., 1997.

YOU, JONG-IL. Macroeconomic Structure, Endogenous Technical Change and Growth. Cambridge Journal of Economics, 18, 1994. 


\section{ENDNOTES:}

${ }^{1}$ Post-Keynesian models of growth and distribution can be grouped in three generations of models. The first generation is composed by balanced growth models as those of Kaldor (1957) and Pasinetti (1962). The main theoretical issue of this generation of models is to determine what conditions must be met in order to produce a full-employment growth path for real output; i.e. the conditions required for equalization between warranted and natural growth rates in Harrod (1939) terms. The second generation of models is not concerned with balanced growth paths. This generation of models considers growth and capital accumulation as an open process, determined by institutions (eg. union power) and "animal spirits" of capitalists. Growth is determined by the firms' desired rate of capital accumulation and real output is demand determined. One example of this class of models is Rowthorn (1981). The first and second generations of models have in common the fact that both deals with no-monetary economies within a linear structure of dynamic equations. The third generation of models - may be inspired by Kregel (1985) critic to the Cambridge Theory of growth and distribution - tried to integrate the real and monetary sides of post-Keynesian theory with in a dynamic framework characterized main ly by non-linearities. Some examples of this class of models are Jarsulic (1988) and Wattanabe (1997). For more details, see Carvalho (2005).

${ }^{2}$ For more details on the concept of monetary economy of production, see Davidson (1978) and Carvalho (1992).

${ }^{3}$ The first, second and third blocks follows Lima (1999).

${ }^{4}$ Or to decrease with the unemployment rate. More details, see Blanchard (1999, p. 305).

${ }^{5}$ This is equivalent of saying that the Central Bank has a real interest rate target.

${ }^{6}$ By means of this equation, we differentiate, amongst others, of Lima (1999), Rowthorn (1981) and Dutt (1984 and 1990). Moreover, the rationale for this investment function can be also found in the work of Dutt (1994), based in the ideas of Kalecki (1971), Schumpeter (1934), and Nelson and Winter (1982). 
${ }^{7}$ Due to the fact of the equation (32) is cubical, there can be three real roots that solve equation $\hat{k}=0$. However, only two of these roots assume positive values in the space $(k-S)$. Besides, applying the total derivative to locus $\hat{k}=0$, we can also verify that $k$ is insensitive to variations in $S$; so that locus $\hat{k}=0$ will be represented by means of two vertical straight lines.

${ }^{8}$ The software used in the simulation was the program Mathematica 4.1.

${ }^{9}$ For Kaldor (1993) the United States of America and the United Kingdom had a propensity to save around 0.7. While Germany would present a propensity to save of 0.8 . 